\title{
Complete denture treatment using lingualized occlusion scheme at the edentulous patient with severely absorbed flat residual ridges: a case report
}

\author{
Bum-Shik Choi, Joon-Seok Lee* \\ Department of Prosthodontics, School of Dentistry, Dankook University, Cheonan, Republic of Korea
}

\begin{abstract}
Many factors should be considered for successful denture treatment at edentulous patients: support, retention, stability, occlusion, esthetics, etc. The patient who has severely absorbed residual ridges, however, treatments are challenging to satisfy those factors. The dentures that use anatomic artificial teeth show good mastication efficiency and esthetics but, can easily lose stability at absorbed ridges. On the contrary, the dentures that use non-anatomic artificial teeth perform better stability but, lower masticatory efficiency and esthetics at absorbed ridges. The lingualized occlusion, using both anatomic and non-anatomic teeth, introduced for compromise those of the pros and cons. At lingualized occlusion, buccal cusps of the teeth do not contact on centric relation. Therefore, direction of the occlusal force towards lingually, then stability of dentures increases. This case report shows the results of the treatment flat residual ridges using complete dentures with ligualized occlusion to increase dentures stability and satisfactory of the patient. (J Dent Rehabil Appl Sci 2017;33(3):207-15)
\end{abstract}

Key words: edentulism; complete denture; artificial tooth; lingualized occlusion

\begin{abstract}
서론
무치악의 수복은 치의학에 있어 항상 도전이 되어왔다. 환자가 치아를 상실해감에 따라서 불용성 위축에 따른 치조골의 흡수가 자연스럽게 진행되게 된다. 무치악의 수복에 있어서도 치과용 임플란트의 사용이 가능하나, 잔존 치조골의 부피, 질이 불량하거나, 환자의 전신상태 및 경제적 사정으로 인하여 총의치로의 수복도 빈번하게 일어난다. 하지만 잔존 치조골의 흡수가 심한 경우, 총의 치 치료에 있어 중요한 지지, 유지, 안정 등을 얻기 힘들 다. ${ }^{1}$ 특히 잔존치조골이 편평한 경우 측방운동 시 총의치 의 안정이 쉽게 상실되는 경우가 많다.

총의치의 교합은 총의치 치료의 성공 요인 중의 하나이 다. ${ }^{2}$ 성공적인 총의치 사용을 위하여 여러 가지 인공치를 이용한 다양한 교합방식이 제시되었고 양측성 균형교합
\end{abstract}

*Correspondence to: Joon-Seok Lee

Professor, Department of Prosthodontics, College of Dentistry, Dankook University, 119, Dandae-ro, Dongnam-gu, Cheonan, 31116, Republic of Korea Tel: +82-41-550-0256, Fax: +82-41-550-1975, E-mail: jseok@hanmail.net Received: July 10, 2017/Last Revision: July 24, 2017/Accepted: July 29, 2017
과 설측 교두 교합은 그 중 하나이다. 인공치아는 그 교 두경사에 따라 해부학적 치아, 비해부학적 치아, 반해부 학적 치아로 나뉘어진다. ${ }^{3}$ 해부학적 치아는 마모되지 않 은 자연치아와 유사하게 생긴 형태로, 교두경사가 높아 좋은 저작효율과 심미성을 지니나, 측방운동 시 교두경 사로 인하여 양측성 균형교합을 달성하기 어렵고 안정성 을 쉽게 상실할 수 있다. 그에 반면, 비해부학적 치아는 교두경사가 없어 저작효율이 낮고 비 심미적이나 측방 운동 시 교두경사가 없어 비교적 양측성 균형교합을 달 성하기 쉽고 안정성 달성에 유리하다. 반해부학적 치아 는 해부학적 치아와 비해부학적 치아의 중간 형태다. 이 에 각 치아를 섞어 사용하여 그 장점만을 얻으려는 노력 이 시도되었고 이것이 설측 교두 교합의 제시로 이어졌 다. 설측 교두 교합은 상악에는 해부학적 치아를, 하악에 는 비해부학적 치아 또는 반해부학적 치아를 사용하며,

CopyrightC 2017 The Korean Academy of Stomatognathic Function and Occlusion. (c) It is identical to Creative Commons Non-Commercial License. 
상악 설측 교두만이 하악의 중심와에 접촉함으로써 교합 을 설측화 한다고 하여 설측 교두 교합이라 명명되었다. ${ }^{3}$ 설측 교두 교합은 교합이 설측화 또는 중심화되어 총의 치의 안정성이 높아지게 되며 상악에 해부학적 치아를 이 용하였기 때문에 저작효율과 더불어 심미성도 확보할 수 있다는 장점이 있다. ${ }^{4}$

본 증례에서는 골흡수가 진행되어 편평한 치조골을 지 닌 완전 무치악 환자에서 설측 교두 교합을 이용한 총의 치 수복으로 심미적, 기능적으로 양호한 결과를 얻었기 에 이를 소개하고자 한다.

\section{증례보고}

본 증례는 당시 75세 남성 환자로 틀니를 다시 제작 하고 싶다는 주소로 내원하였다. 임상적 및 방사선학적 검사 결과 양악이 무치악이었으며 치조골 흡수가 상당 량 진행된 상황이었다. 상악의 치조제는 흡수가 진행되
어 구개에서 치조제로 이행되는 형태로, 전반적으로 편평 한 양상을 보였다(Fig. 1). 하악 역시 치조골 흡수가 진행 된 상태였고 치은점막경계부가 치조정에 근접할 정도여 서 명확한 치조제가 관찰되지 않는 상태였다. 하악 협측 의 협붕 부위를 촉진할 경우 외사선이 오히려 치조제 보 다 상방에 위치하고 있어 외사선이 상대적으로 융기되 어 볼록하게 만져졌다. 의학적 병력으로는 요추 치료 중 이라고 하였으며, 치의학적 병력은 양악이 무치악이 된지 10 여년이 되었고 기존의 의치는 10 년 정도 사용하였다고 진술하였다.

기존의 사용중인 의치는 변연이 매우 짧은 형태로 제 작된 상태였으며 인공치아의 교합면이 매우 마모되어 수 직고경이 감소된 상태였다. 수직고경을 회복하기 위하여 예비인상을 채득 후 임시의치를 제작하여 장착하였다. 상악 전치부는 구순선에 맞추고 이를 Camper's line에 일 치시켜 구치부를 맞추었으며, 하악은 중심위로 과두를 유도하여 상악에 맞도록 교합평면을 맞추되, 안정위에

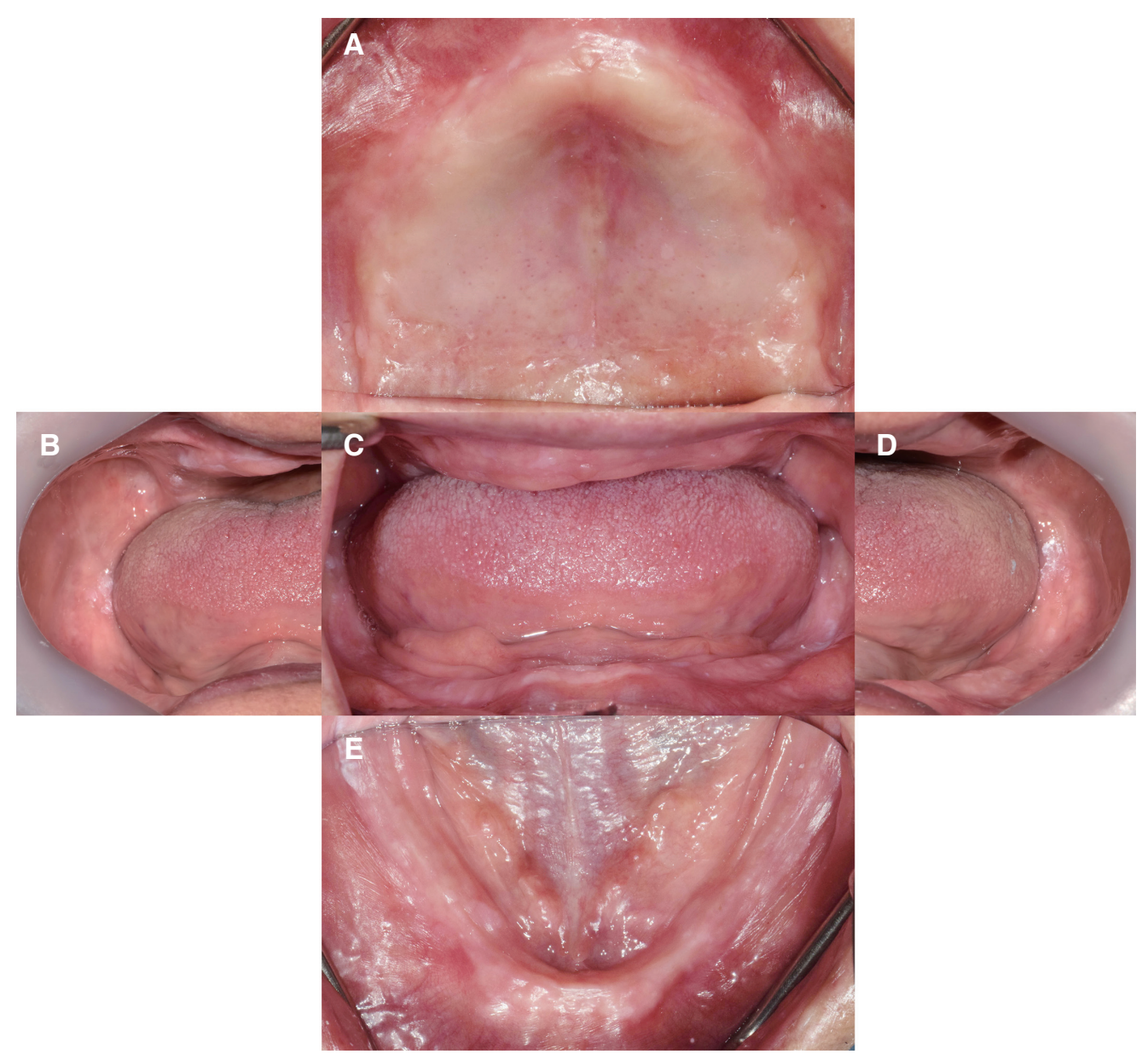

Fig. 1. (A) Upper, (B) right lateral, (C) frontal, (D) left lateral and (E) lower views of intraoral photos at the initial examination. Severely absorbed ridges observed. 
서 상, 하 소구치 부위의 교합제 간 거리가 $3 \mathrm{~mm}$ 가 되도 록 하였다. 이를 조절하여 사용하면서 1달간 관찰하였을 때 환자는 증가된 수직고경에 잘 적응하였다. 하지만 임 상적 검사 시 상악 임시의치는 측방운동 시 안정성이 떨 어졌다. 이에 하악 임시의치 인공치아 구치부의 교두각도 를 조정하여 감소시키고, 상악 임시의치 인공치아 구치 부의 협측 교두를 삭제하여 설측 교두 교합을 임의적으 로 형성해 주었다. 그 결과 환자는 기능 및 안정성에 만족 하였다. 이에 최종의치는 치아배열을 설측 교두 교합으 로 배열하기로 계획하였다.

한달 동안 임시의치 사용 후 예비인상을 채득하여 개 인트레이를 제작하였다(Fig. 2). 인상방법은 선택적 가압 인상으로 계획하였고 상악은 후방구개폐쇄부, 하악은 치
조정을 제외한 모든 부분을 가압하기로 결정하여 이에 맞게 트레이를 설계하였다. 모델링 컴파운드(Peri compound, GC Corp., Tokyo, Japan)로 변연 형성 후 부가중 합형 실리콘 인상재(Exadenture, GC Corp.)로 최종 인상 을 채득하였다(Fig. 3). 채득된 인상체에 4형 치과용 석고 (Fuji rock EP, GC Corp.)를 주입하여 주모형을 제작하 였다.

주모형 상에서 자가중합 레진(Quicky resin, NISSIN, Kyoto, Japan)을 이용하여 통법에 따른 기초상과 왁스 교 합제를 제작하였다. 이를 이용하여 환자의 중심위를 유 도한 상태에서의 악간관계를 채득하였다. 교합평면 설정 은 임시의치 제작 시와 동일하게 하였으며(Fig. 4), 수직 고경도 일치하도록 조정하였다.

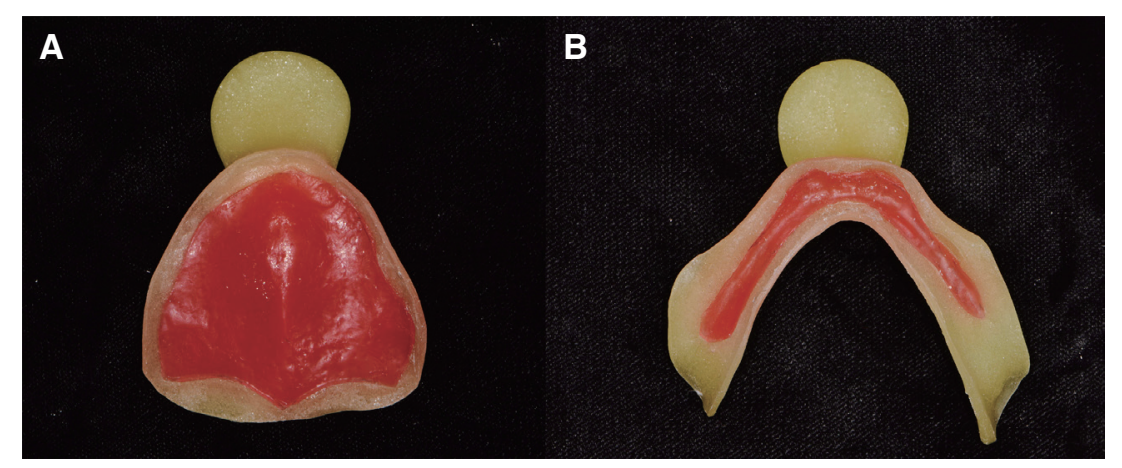

Fig. 2. Individual trays of (A) upper and (B) lower jaws for selective pressure impression technique.

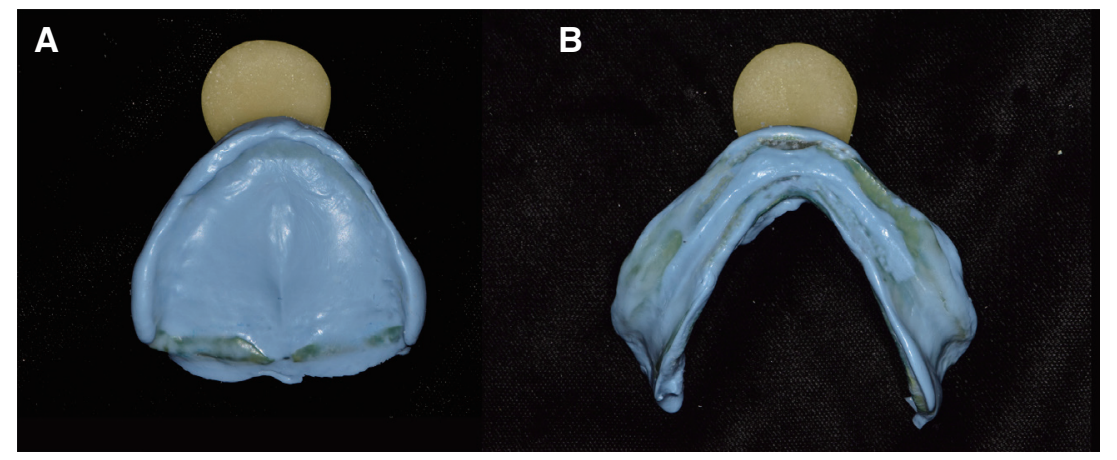

Fig. 3. Impressions of (A) upper and (B) lower jaws that taken by individual trays and addition silicone impression materials.

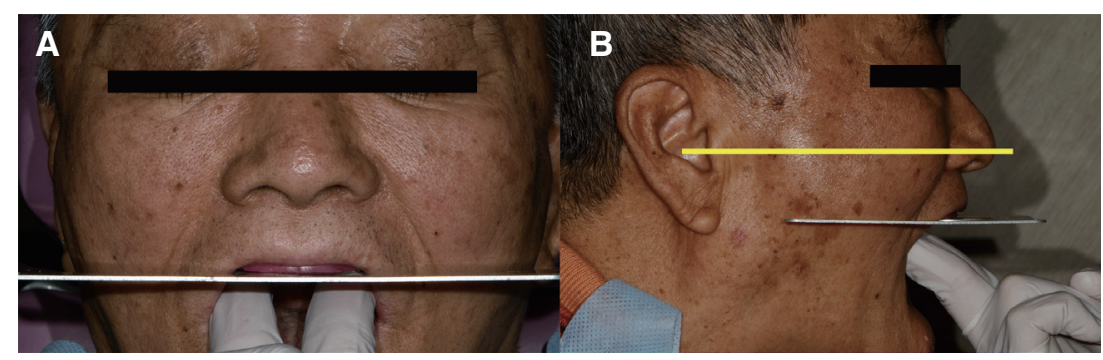

Fig. 4. (A) Frontal and (B) lateral views of occlusal plane setting. 
주모형을 교합기(Hanau ${ }^{\mathrm{TM}}$ Modular Articulator System 190, Whip Mix Corp, Port Collins, USA)에 마운팅 하고 통상적인 하악법을 이용하여 인공치아의 배열을 시행하였다. 하악 전치를 우선적으로 배열 후, 상악 전 치는 심미성을 지님과 동시에 수평피개량이 $1 \mathrm{~mm}$ 가 되 도록 배열하였다. 구치부의 인공치아는 설측 교두 교합 을 위하여 특별히 제작된 제품(SR Ortholingual ${ }^{\circledR}$ DCL, Ivoclar Vivadent Ltd, Amherst, USA)을 사용하였다. 하 악 구치부를 Spee 만곡과 Wilson 만곡을 부여하여 배열 하였으며 그에 맞추어 상악 구치를 배열할 때, 상악 설측 교두가 하악 구치의 와에 접촉되도록 하고 상악 협측 교 두는 대합치에 접촉하지 않도록 하여 설측 교두 교합의 이론에 일치하도록 하였다(Fig. 5). 교합기의 과로경사는 시상과로 $30^{\circ}$, 측방과로 $15^{\circ}$ 로 임의의 평균값을 사용하 여 설정하였으며 이에 따른 교합기 상에서의 측방 운동 및 전방 운동 시 설측 교두 교합이 제대로 부여되었는지
를 확인하였다(Fig. 6).

납의치 시적 시 인공치 배열 및 교합관계를 최종확인 하여 부여된 설측 교두 교합이 환자에게 기능하는지 확 인하였다. 심미적 및 기능적인 사항에 있어 환자의 동의 를 얻은 후 교합기 재부착용 지그를 플라스터를 이용하 여 제작하고, 통상적인 방법으로 매몰하고 열중합 의치 상 레진(Lucitone 199, Dentsply, York, USA)을 이용하 여 최종의치를 제작하였다. 해함 후 기공실 재부착을 통 해 중합 오차를 제거하였다. 최종 장착 시 교합관계를 중 심위에서 재채득하였고(Fig. 7) 이를 이용하여 진료실 재 부착을 시행하여 설측 교두 교합이 제대로 부여되었는지 를 확인하였다. 이 후 환자의 구강 내에서 직접 교합을 확 인하였다(Fig. 8). 최종 장착된 의치는 만족할만한 유지 력, 안정성을 보였으며, 기능적, 심미적으로 만족할만한 결과를 보였다(Fig. 9,10).

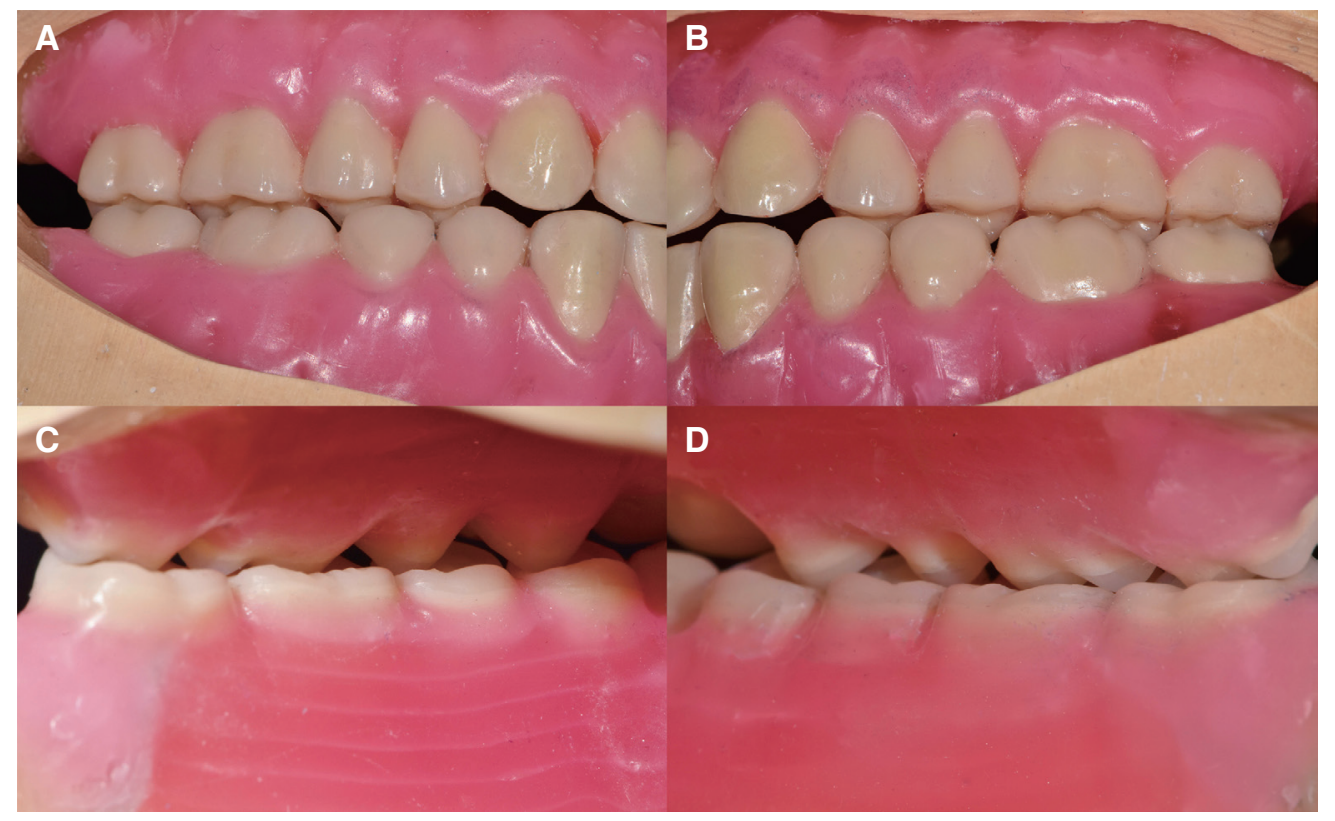

Fig. 5. (A) Right buccal, (B) left buccal, (C) left lingual and (D) right lingual views of wax dentures.

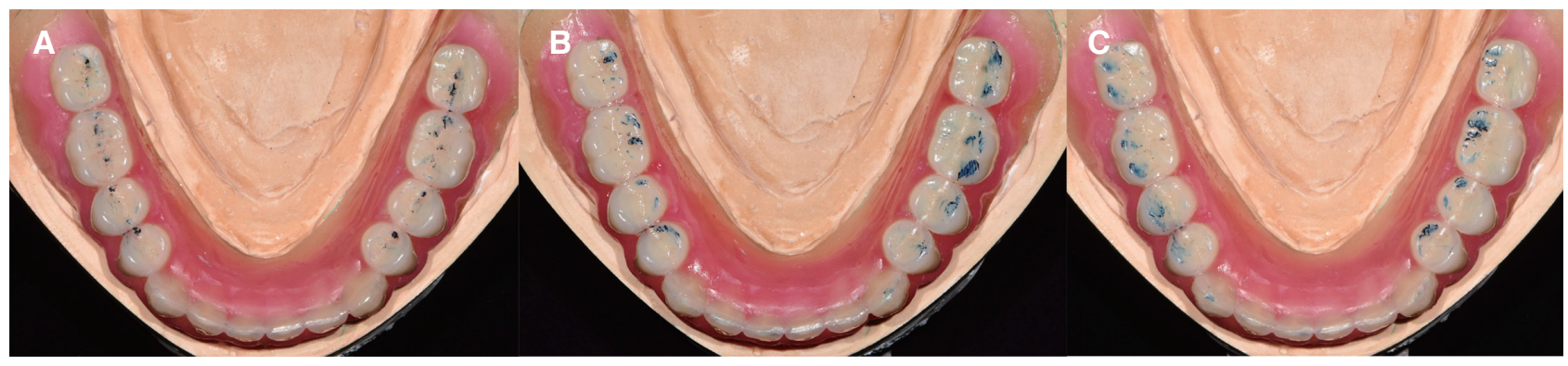

Fig. 6. Occlusal contact point of $(A)$ centric relation, $(B)$ left lateral excursion and $(C)$ right lateral excursion. 


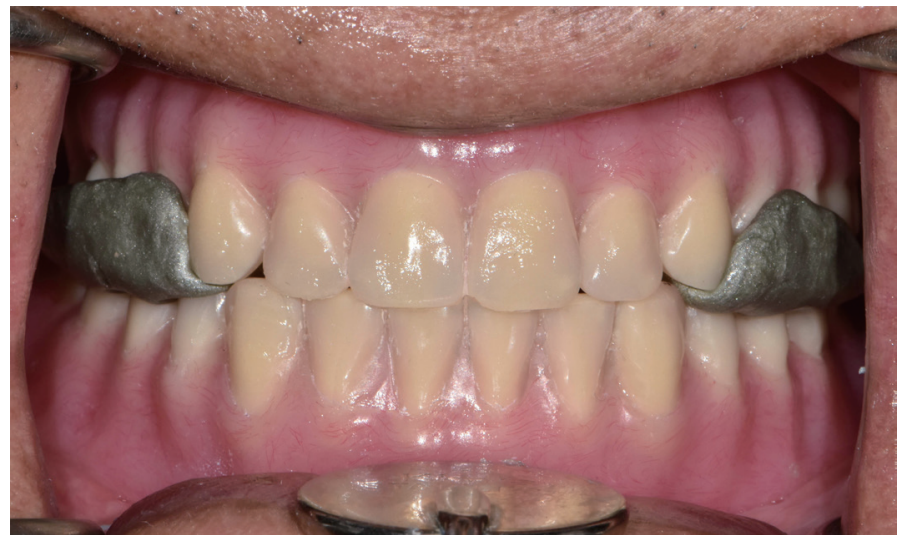

Fig. 7. Occlusion registration with alu-wax for clinical remounting.

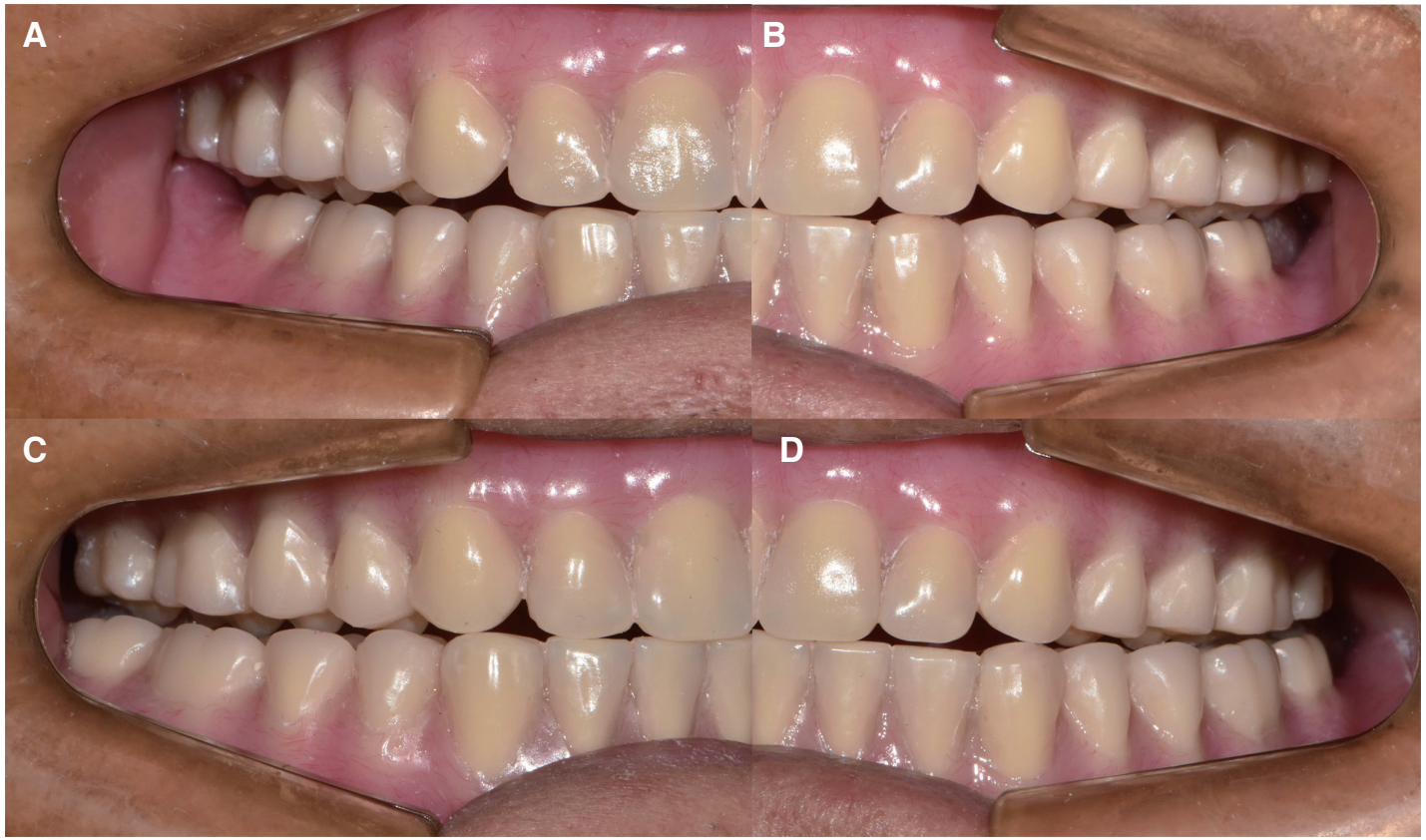

Fig. 8. Confirmation of the lingualized occlusion at intraoral denture delivery phase. The photos of (A) right, (B) left non-working side and (C) right, (D) left working side showed upper palatal cusps evenly contacted to lower molars.

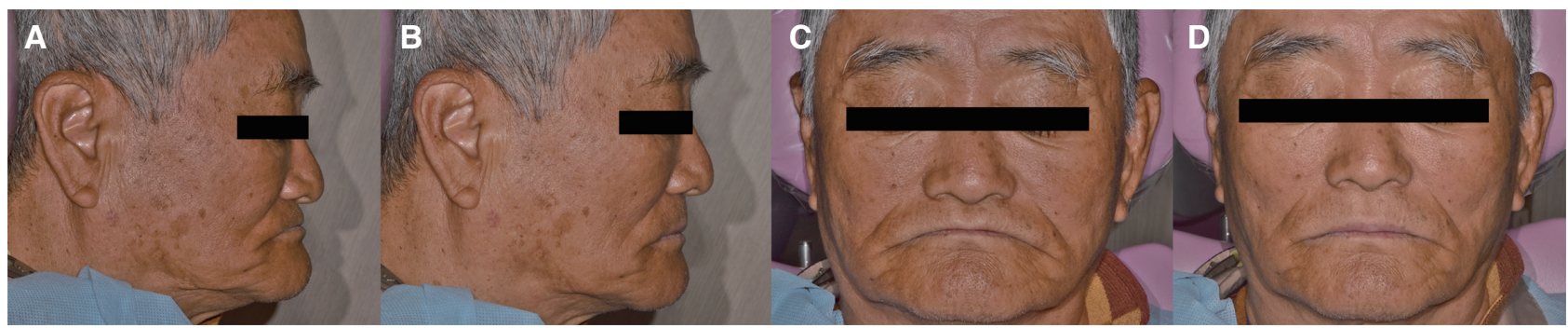

Fig. 9. Lateral and frontal view of extraoral photos of the patient before and after treatment. (B) Lateral and (D) frontal facial profiles were improved esthetically than (A) lateral and (C) frontal facial profiles with old dentures. 


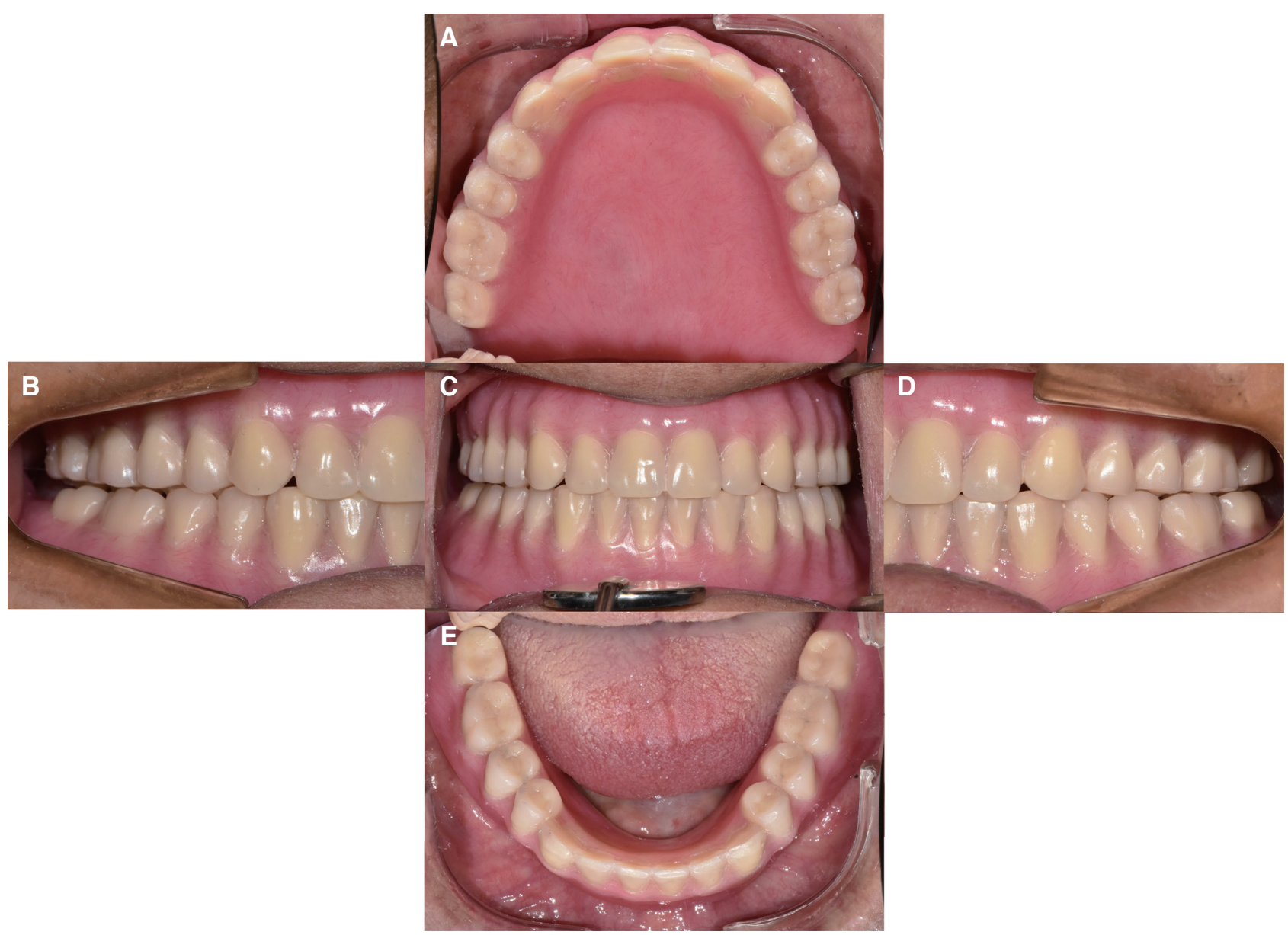

Fig. 10. (A) Upper, (B) right lateral, (C) frontal, (D) left lateral, (E) lower views of the intraoral photos after treatment at centric relation state.

\section{고찰}

Gysi가 1927년에 초기 형태의 설측 교두 교합의 개념 을 제시한 이래 많은 변화가 이루어져 현재와 같은 개념 에 이르렀다. ${ }^{5}$ 그 과정에서 설측 교두 교합의 유용성을 입증하기 위해 많은 연구들이 시행되었다. 설측 교두 교 합은 해부학적 인공치아와 비해부학적 인공치아를 혼용 함으로써 각각의 치아들의 장점과 단점을 절충하고자 하였기에 ${ }^{3}$ 이를 기존 방식의 교합형태와 비교한 연구들 이 활발하게 이루어졌다. Clough 등 ${ }^{4}$ 의 연구에 따르면, 비해부학적 치아만을 구치부에 사용한 단일 평면 교합 (monoplane)과 설측 교두 교합을 둘 다 사용해본 환자 들의 $67 \%$ 는 설측 교두 교합을 더 선호하였다고 하였으 며, Sutton 등 ${ }^{6}$ 도 단일 평면 교합보다 설측 교두 교합에서 환자의 만족도가 높다고 보고하였다. Kawai 등에 따르
면 하악 치조제의 흡수가 심한 환자에서 양측성 균형교 합보다 설측 교두 교합을 더 선호한다고 하였으며, 이와 유사한 결과를 보인 연구들은 설측 교두 교합을 사용할 경우에 의치의 안정성이 증가하고 저작효율이 증가하였 다고 보고하였다..$^{7-9}$

본 증례에서는 설측 교두 교합으로 새로 제작한 의치 를 다른 교합형태와 비교할 수는 없었으나, 여러 문헌에 서 언급하는 바처럼 잔존 치조골 흡수가 진행되어 편평 한 치조제를 지닌 환자에서 좋은 안정성과 심미성, 양호 한 저작 기능에 따른 환자의 만족도를 얻을 수 있었다. 하지만, 양측성 균형교합과 설측 교두 교합에서 유의한 차이를 보이지 않았다고 보고된 연구도 있다. ${ }^{6,10}$ 특히, Zhao 등 ${ }^{11}$ 의 2013년의 systematic review에서 설측 교두 교합이 양측성 균형교합보다 우월하다는 근거는 부족하 며, 양측성 균형교합만큼 성공적으로 사용할 수 있다는 
결과를 보고하였다. 따라서 본 증례에서도 양측성 균형 교합을 이용한 새 의치를 추가적으로 제작한 후 더 나은 것을 환자에게 선택하도록 하였다면 더욱 이론적 근거가 충분한 치료를 시행할 수 있었을 것으로 사료된다.

설측 교두 교합이 양측성 균형교합에 비해 상대적으 로 유리한 점 중 하나는 치아배열의 편리함이다. 하악 구 치부의 중심와에서 중심위 접촉점이 형성되며, 측방위 및 전방위에서 Spee 만곡과 Wilson 만곡을 따라서 접촉이 형성되기 때문이다. ${ }^{3}$ 이는 기공과정의 간편화에 따른 시 간단축으로 이어질 수 있다. 의치의 기공과정에서 의치에 가장 흔하게 오차를 야기하는 요소는 중합과정에서의 변 형이다. ${ }^{12} \mathrm{Basso}$ 등 $^{13}$ 의 연구에 따르면, 설측 교두 교합으 로 교합형태가 부여된 채로 중합된 의치는 양측성 균형 교합으로 교합형태가 부여된 의치와 중합 시 오차에 유 의한 차이가 없다고 하였다. 이에, 치아배열의 편리함을 고려한다면 설측 교두 교합은 기공과정도 상대적으로 유 리한 교합형태라고 사료된다.

설측 교두 교합은 여러 가지 교두 각도를 지닌 인공치 아들을 혼용한 방법이다. 설측 교두 교합을 부여하는 방 법은 여러 가지 방법으로 시도되었었는데, 그 중 하나는 교두각도에 변화를 주는 것이었다. ${ }^{14}$ 인공치아의 교두각 도에 따라서 의치의 안정성, 저작효율, 지지조직에 가해 지는 압박도 등에 차이가 생기게 된다. ${ }^{15}$ 본 증례에서는 기성 설측 교두 교합용 인공치아를 사용하였기에 기존의 교두경사에서 많은 변화는 없었을 것으로 생각된다. 그 러나 환자의 더 높은 만족도를 위하여 다양하게 교두경 사의 변화를 주는 것이 시도되고 있다고 한다. 인공치아 의 조정 또는 다양한 회사의 설측 교두 교합용 인공치아 의 사용으로 다양한 교두경사를 지닌 인공치아들을 적용 해보았다면 더욱 환자의 만족도를 높일 수 있었을 것으 로 생각된다.

\section{결론}

본 증례에서는 치조골 흡수가 진행되어 편평한 잔존치 조제를 지닌 환자에서 설측 교두 교합을 부여한 양악 총 의치를 사용하여 치료하였다. 설측 교두 교합으로 제작 된 의치는 편리한 인공치배열에 따른 기공과정에 용이함 을 보였으며, 뛰어난 안정성, 심미성 및 저작효율을 나타 냈다.

\section{ORCID}

Bum Shik Choi https://orcid.org/0000-0003-3698-5289

Joon-Seok Lee https://orcid.org/0000-0003-2962-1380

\section{References}

1. Kwon WI, Song YG, Lee JS. Complete denture rehabilitation of fully edentulous patient with severe bone resorption and class II jaw relation using piezography. J Korean Acad Prosthodont 2016;54:445-50.

2. Kawai Y, Ikeguchi N, Suzuki A, Kuwashima A, Sakamoto R, Matsumaru Y, Kimoto S, Iijima M, Feine JS. A double blind randomized clinical trial comparing lingualized and fully bilateral balanced posterior occlusion for conventional complete dentures. J Prosthodont Res 2017;61:113-22.

3. Becker CM, Swoope CC, Guckes AD. Lingualized occlusion for removable prosthodontics. J Prosthet Dent 1977;38:601-8.

4. Clough HE, Knodle JM, Leeper SH, Pudwill ML, Taylor DT. A comparison of lingualized occlusion and monoplane occlusion in complete dentures. J Prosthet Dent 1983;50:176-9.

5. Gysi A. Special teeth for cross-bite cases. Dent Digest 1927;33:167-71.

6. Sutton AF, McCord JF. A randomized clinical trial comparing anatomic, lingualized, and zero-degree posterior occlusal forms for complete dentures. J Prosthet Dent 2007;97:292-8.

7. Ohnuki M, Nishiyama Y, Hosoi T, Tojo T, Nishimura K. Functional efficacy of full balanced occlusion and lingualized occlusion evaluated from morphological differences in the edentulous alveolar ridge. Prosthodont Res Pract 2002;1:31-40.

8. Matsumaru Y. Influence of mandibular residual ridge resorption on objective masticatory measures of lingualized and fully bilateral balanced denture articulation. J Prosthodont Res 2010;54:112-8.

9. Deniz DA, Kulak Ozkan Y. The influence of occlusion on masticatory performance and satisfaction in complete denture wearers. J Oral Rehabil 2013;40:91-8.

10. Heydecke G, Vogeler M, Wolkewitz M, Türp JC, 
Strub JR. Simplified versus comprehensive fabrication of complete dentures: patient ratings of denture satisfaction from a randomized crossover trial. Quintessence Int 2008;39:107-16.

11. Zhao K, Mai QQ, Wang XD, Yang W, Zhao L. Occlusal designs on masticatory ability and patient satisfaction with complete denture: a systematic review. J Dent 2013;41:1036-42.

12. Lim SR, Lee JS. Three dimensional deformation of dry-stored complete denture base at room temperature. J Adv Prosthodont 2016;8:296-303.

13. Basso MF, Nogueira SS, Arioli-Filho JN. Compari- son of the occlusal vertical dimension after processing complete dentures made with lingualized balanced occlusion and conventional balanced occlusion. J Prosthet Dent 2006;96:200-4.

14. Phoenix RD, Engelmeier RL. Lingualized occlusion revisited. J Prosthet Dent 2010;104:342-6.

15. Arksornnukit M, Phunthikaphadr T, Takahashi H. Pressure transmission and distribution under denture bases using denture teeth with different materials and cuspal angulations. J Prosthet Dent 2011;105:127-36. 


\section{심한 치조골 흡수로 인해 편평한 치조제를 보이는 완전 무치악 환자에서 설측 교두 교합을 이용한 의치 수복 증례}

\section{최범식, 이준석*}

단국대학교 치과대학 치과보철학교실

총의치 치료에서는 지지, 유지, 안정, 교합, 심미 등 고려할 요소가 많으나 치조골 흡수가 심한 경우, 해당 요인을 갖추기 어렵다. 해부학적 치아를 사용할 경우 좋은 저작효율과 심미성을 기대할 수 있으나, 흡수된 치조골에서는 안정이 저하될 수 있으며 비해부학적 치아는 이와 반대의 효과를 나타낸다. 이에 치아를 혼용하는 설측 교두 교합이 제시되었다. 설측 교두 교합에서 상, 하악 협측 교두는 중심위, 측방위에서 접촉되지 않고 교합접촉위치가 설측화 또는 중심화되어 의치의 안정성이 증대될 수 있다. 본 증례는 상하 치조제의 흡수가 진행되어, 상악에서 편평한 치조제를 보이는 경우로, 설측 교 두 교합을 이용한 총의치를 이용하여 치료함으로써 의치의 안정성과 환자의 만족도를 높였기에 이를 보고하는 바이다.

(구강회복응용과학지 2017;33(3): 207-15)

주요어: 완전 무치악; 총의치; 인공치아; 설측 교두 교합 